\title{
Civil Settlement During Rape Prosecutions
}

\author{
William H.J. Hubbard†
}

[E]ither a guilty man bought his way out of a trial or an innocent man was wrongly accused in a successful extortion attempt. ${ }^{1}$

A defendant in a criminal rape prosecution faces the prospect of a civil action brought by the complainant. ${ }^{2}$ Sometimes, the defendant will offer to settle the potential civil case with the complainant while the prosecution is still pending. Following settlement, the complainant may request that the charges be dropped or refuse to cooperate with the prosecution.

A prosecution for a robbery or an assault still could proceed without the cooperation of the alleged victim, relying instead on other witnesses and physical evidence. But a rape prosecution is different. A rape prosecution almost always relies heavily on the complainant's testimony. If the complainant is no longer interested in pursuing the case, even the most zealous prosecutor may have little choice but to drop the charges. ${ }^{3}$ Regardless of how the

† B.A.M.A. (Economics) 1997, University of Southern California; J.D. Candidate 2000, The University of Chicago.

${ }_{1}^{1}$ Debra Saunders, Uneven Scales Tilt the Crime Bill, Times-Picayune B5 (Feb 7, 1994) (criticizing government tolerance of civil settlements that lead to dropped criminal charges). Consider the following account:

[A woman accused a man of raping her at a cocktail party.] The man denied the charges, but after the woman hired a civil lawyer known for winning big settlements in such cases, the man told his attorney to offer the woman money. The attorney contacted the woman's civil lawyer and offered to pay $\$ 850,000$ for her alleged pain and suffering, but the offer would only be good if the criminal case was resolved in the defendant's favor.... [T] The woman decided not to testify and the case was dismissed. She took her $\$ 850,000$ and moved to the Caribbean.

Tobia Smith and Bob Edwards, Paying Off on Sex Crimes, National Public Radio Morning Edition (Apr 21, 1998) (Smith, reporter, recounting story told to NPR by a lawyer).

${ }^{2}$ Because the settlements that are the subject of this Comment occur before the criminal trial, this Comment uses the term "complainant" rather than "victim" when discussing cases where the fact of the rape is in dispute.

${ }^{3}$ See Jeanne C. Marsh, Alison Geist and Nathan Caplan, Rape and the Limits of Law Reform 88 (Auburn House 1982) ("In Detroit, analysis of the Sex Crimes Unit data reveals that virtually half of the [sex offense] cases dismissed are accounted for by the complainant's refusal to prosecute or appear at trial."). See also Smith and Edwards, Paying Off on Sex Crimes, National Public Radio Morning Edition (cited in note 1) (quoting Wendy Murphy, former prosecutor: "In terms of intimate violence, there tend to be only two witnesses, 
alleged rapist and the alleged victim reached their settlement, one fewer rape prosecution will go forward.

Because the rape victim's testimony is central to the success of a rape prosecution, pretrial settlement ${ }^{4}$ in rape cases can undermine the enforcement of rape law. A guilty defendant can use pretrial settlement to influence the complainant not to cooperate with the prosecution. Pretrial settlement also offers an opportunity for a false accuser to extort a payment from an innocent defendant before a trial exonerates the accused.

Rape law enforcement is a pressing concern. Estimates of the incidence of rape vary widely, but even relatively conservative estimates indicate hundreds of thousands of rapes per year, ${ }^{5}$ suggesting that millions or tens of millions of women have been victims of rape or attempted rape. Other estimates provide even more mind-boggling numbers. ${ }^{6}$ Further, even women never victimized by rape may experience rape as an ever-present danger. ${ }^{?}$

one of whom is accused of the crime and has a Fifth Amendment right not to testify. The other one, the woman, typically, makes or breaks the case. If she doesn't testify, there's usually no evidence left over.").

"In this Comment, "pretrial settlement" refers to a payment from the defendant to the complainant ostensibly made to settle any civil claims arising from the alleged rape. Such payments are made while the criminal prosecution is still pending.

- The Department of Justice has estimated 130,000 rapes per year. National Victim Center and Crime Victims Research and Treatment Center (National Victim Center"), Rape in America: A Report to the Nation 3 (Apr 23, 1992).

6 Id at 2 (reporting that one out of every eight women surveyed was a victim of rape at some point in her lifetime); Virginia State Council of Higher Education and the Task Force on Campus Rape ("Task Force on Campus Rape"), Sexual Assault on Virginia's Campuses 17-18 (Virginia Senate 1992) (finding that 5 percent of women students at Virginia college campuses were victims of attempted rape, which is consistent with data on rape covering college campuses nationwide); Mary P. Koss, Christine A Gidycz and Nadine Wisniewski, The Scope of Rape: Incidence and Prevalence of Sexaal Aggression and Victimization in a National Sample of Higher Education Students, $55 \mathrm{~J}$ Consulting \& Clinical Psych 162, 168 (1987) (reporting that "since the age of fourteen, 27\% of college women reported experiencing an act that met the legal definition of rape, which includes attempt"). However, it should be noted that estimating the incidence of rape is very diffcult. Lorraine Dusky, Still Unequal: The Shameful Truth About Women and Justice in America 380 (Crown 1996) (stating that "[r]ape statistics have always been ambiguous because of the difficulty in collecting them"); Task Force on Campus Rape, Sexual Assault on Virginia's Campuses at 27 ('Because of the underreporting and the overlap in the statistics kept by various agencies, the number of actual incidents is virtually impossible to determine on the basis of official crime statistics."); Margaret T. Gordon and Stephanie Riger, The Female Fear 35 (Free Press 1989) (discussing discrepancies in statistics and noting that " $[\mathrm{p}]$ erhaps the greatest source of error in the reported rate of rape is the nonreported incidents"). Changes in the wording of a question can transform the results. Dusky, Still Unequal at $\mathbf{3 8 0}$ (citing National Victim Center, Rape in America (cited in note 5) and acknowledging that use of the word "rape," rather than a description of forced sex, results in "the number of positive responses go[ing] down by about half").

7 Gordon and Riger, The Female Fear at 2 (cited in note 6) ("Most women experience fear of rape as a nagging, gnawing sense that something awful could happen ... . Women's fear of rape is a sense that one must always be on guard."). Evidence indicates 
Unfortunately, effective rape law enforcement is a delicate and exceedingly difficult matter. Few victims report that they have been raped, ${ }^{8}$ and those that do may be reluctant to testify or participate in criminal discovery. ${ }^{9}$ A rape victim may desire justice, but ultimately she may accept an offer of payment in order to avoid the trauma of continuing investigation and possible trial. Hopefully, the victim achieves closure. But the cost to society is high. If criminal sanctions are not pursued, their ability to prevent future crimes through incapacitation is lost. Pretrial settlements in the rape context dilute the deterrent value of settlement because the victim's desire to avoid trial weakens her bargaining position. Pretrial settlement may cause prosecutors to lose confidence that rape victims will see their cases through. Perhaps most troubling, settlement perpetuates the extremely low rates of conviction for rape,$^{10}$ giving credence to the myths that rape is not common and rape complainants are not credible.

Because there are few cases involving pretrial settlement during rape prosecutions, ${ }^{11}$ it is not clear whether courts would apply bribery and witness tampering laws to pretrial settlements that induce rape complainants to avoid trial. Although such laws are broadly drafted and usually broadly construed, courts may be reluctant to entertain prosecutions based on civil settlements. This Comment argues that courts should scrutinize pretrial set-

that a rapist is more likely to be a nonstranger-for example, a date-than a stranger. See, for example, National Victim Center, Rape in America at 4 (cited in note 5) (finding that only 22 percent of rape victims are raped by strangers). The prevalence of date rape forces women to be on guard even in intimate social situations.

- National Victim Center, Rape in America at 6 (cited in note 5) (citing National Women's Study finding that 84 percent of rape victims do not report the rape); Task Force on Campus Rape, Sexual Assault on Virginia's Campuses at 27 (cited in note 6) (noting that "only 2-3 percent of victims report [the rape] to anyone in authority"); Candace Waldron, et al, Sexual Assault in Massachusetts 1985-1987: Shattering the Myths 33 (Mass Dept of Public Health 1990) (finding that only 40 percent of victims of completed rapes reported the rape to the police).

- See Waldron, et al, Sexual Assault in Massachusetts at 42 (cited in note 8) (finding that only 28 percent of sample intended to prosecute). See also Part I.B.

${ }^{10}$ Morrison Torrey, When Will We Be Believed? Rape Myths and the Idea of a Fair Trial in Rape Prosecutions, 24 UC Davis L Rev 1013, 1024 (1991) (noting that estimates of the percentage of convictions that follow rape vary from 1 to 4 percent); Marsh, Geist and Caplan, Rape and the Limits of Law Reform at 31 (cited in note 3) (citing studies in three jurisdictions that indicate 4 to 5 percent of rape arrests end in convictions); Dusky, Still Unequal at 383 (cited in note 6) (citing a Portland, Oregon, study that found that only 2 percent of rapes end in imprisonment).

"Part II discusses the present law regulating the influencing of witnesses or victims. See also Marsh, Geist and Caplan, Rape and the Limits of Law Reform at 85 (cited in note 3) ("Law primarily governs the conduct of the most visible aspect of a case, its culmination in trial. But it leaves untouched many steps in case processing that are crucial to determining whether a case ever reaches the courtroom."). 
tlements in rape prosecutions for violations of statutes prohibiting influence over victims and witnesses. ${ }^{12}$ Part $I$ outlines the ways that pretrial settlement in rape prosecutions can weaken the enforcement of rape law. Part II surveys tampering statutes and their application to cases involving situations like pretrial settlement. Part III argues that courts should construe tampering statutes to prohibit pretrial settlements intended to influence the complainant to get the rape charges dropped. Such scrutiny would conform to both the text and purposes of tampering statutes. Part IV argues that this proposal would ameliorate the harms of pretrial settlement.

\section{The EfFects of PRETRIAL SETTLEMENT IN RAPE PROSECUTIONS}

Parties, even potential parties, to civil litigation are generally free to settle existing or potential claims. This freedom to settle can yield many benefits: it alleviates the public and private costs of civil trials, eliminates the uncertainty and delay of litigation, and allows parties, through contract, to craft the precise remedies they desire. Settlement provides parties to a dispute the maximum amount of autonomy in resolving their affairs.

Although settlement often benefits the parties involved, when a defendant and a complainant in a rape prosecution settle before the resolution of the criminal case their behavior should be suspect. First, pretrial settlement allows a defendant to influence the complainant's participation in the criminal prosecution. In rape cases, the alleged victim and the star witness are the same person; thus, by settling with the victim, a defendant can in effect make payments to a witness in a rape trial. Because the victim and the witness are the same person, the suspect nature of the payments is masked. Second, pretrial settlement can occur in a coercive context. For example, the defendant may be able to exploit the complainant's fear of a harrowing trial to achieve a favorable settlement. Third, pretrial settlement is a way for a false accuser to use state resources to pressure the defendant, enabling her to extort money from an innocent defendant. Finally, settlement imposes costs on society as a whole. It undermines the expressive and deterrent effects of criminal sanctions and may commodify rape.

12 This Comment refers to these laws collectively as "tampering statutes." See note 46. 
A. Influencing Complainants Not to Cooperate with the Prosecution

Any civil settlement before a criminal trial, as a payment from the defendant to the complainant, may be suspect because many payments to witnesses and victims are illegal. In rape cases, pretrial settlement is especially suspect because the potential civil plaintiff (the complainant) is also the linchpin to the criminal trial. Explicitly or implicitly, the defendant may condition the payment on a favorable outcome in the criminal prosecution. Although the prosecutor controls whether a prosecution goes forward, the complainant can ensure that the state will abandon the prosecution by refusing to cooperate with the prosecution in various ways: asking the prosecutor to drop the charges, failing to appear at judicial proceedings, refusing to testify, or testifying favorably to the defendant. As Part III demonstrates, a settlement intended to affect the complainant's participation in the prosecution violates tampering statutes.

Although case law provides several examples of payments conditioned explicitly on complainant noncooperation with the prosecution, ${ }^{13}$ pretrial settlements can influence complainants in much more subtle ways. ${ }^{14} \mathrm{~A}$ civil settlement easily can be structured to ensure that the victim will try to keep the case from being prosecuted. For example, the value of the settlement could be paid out over a period of years exceeding the statute of limitations for the crime or the amount of the settlement payments could be tied to the defendant's future earnings. ${ }^{15}$

\section{B. Coercive Nature of Pretrial Settlement}

Fear of the trauma caused by participating in the rape prosecution and by testifying at trial may compel rape victims to settle the civil case prior to the criminal trial and end all proceedings against the defendant. ${ }^{16}$ Rape complainants have powerful rea-

\footnotetext{
${ }^{13}$ See Part II.B.

"As one attorney put it, defendants "settle the civil case and hope for the best, quote, unquote." Susan D. Etkind, A Hazy, Hazardous Line, Conn L Trib (Oct 20, 1997).

${ }^{13}$ Legal Ethics: Can Settlement Buy Accuser's Silence?, Conn L Trib 12 (Feb 14, 1994) (noting less obvious ways than explicit agreement for the defendant to prevent the victim from testifying). If the settlement payments are tied to the defendant's future earnings, the victim will have significant incentives to keep the defendant out of jail. Furthermore, the plaintiff may feel that pursuing a prosecution may provoke the defendant to breach the settlement agreement.

${ }^{16}$ See James E. Lobsenz, Prosecutorial Management of the Uncooperative VictimWitness, 15 Crim L Bull 301, 311-18 (July-Aug 1979) (finding that, in criminal trials, witnesses are uncooperative because of "courtroom phobia," fear of retaliation, and the inconvenience of trial; arguing that complainants in criminal prosecutions should be compelled
} 
sons for not wanting to testify at trial. ${ }^{17}$ Historically, defense attorneys subjected complainants to humiliating crossexamination. ${ }^{18}$ Although rape shield laws now limit questions about a complainant's sexual history, ${ }^{19}$ testifying about sexual violence remains a traumatic experience for many women. ${ }^{20}$ Further, a complainant may wish to avoid public exposure as a rape victim. ${ }^{21}$ Painful public scrutiny and the stigma attached to being a rape victim may provide sufficient incentive for a rape victim to make a pretrial settlement in exchange for getting the charges against the defendant dropped. Consequently, defendants can use complainants' fear of stigma to pressure them to settle.

Postponing the possibility of settlement until after the criminal case goes to trial or is plea bargained will partially remedy this problem of coercion. In addition, it will often benefit the victim: a conviction gives the complainant tremendous bargaining leverage in a civil suit, because liability has been established. Despite this potential advantage, the complainant-fearful of a trial

to testify; but "conced[ing] that the case for nonprosecution because of a rape victim's desire to avoid the painful experience of testifying in court is a very strong one").

${ }^{17}$ Torrey, 24 UC Davis L Rev at 1030 (cited in note 10) ("Shame and fear are primary considerations for many [rape victims].... [T] he experience of a trial is grueling and frequently provokes responses in the victim similar to those caused by the actual rape.").

is Stephen J. Schulhofer, Unwanted Sex The Culture of Intimidation and the Failure of the Law 28 (Harvard 1998) (listing questions about use of birth control, sexual activity, adulterous affairs, even whether the complainant had ever been employed as a cocktail waitress).

${ }^{19}$ FRE 412 is the federal rape shield statute. See also Schulhofer, Unwanted Sex at 30 (cited in note 18); Marsh, Geist and Caplan, Rape and the Limits of Law Reform at 68-69 (cited in note 3) (reporting a Michigan study indicating that rape law reform has made victims' experiences less traumatic).

${ }^{20}$ Rape shield laws are no guarantee that trial will not be an ordeal for the complainant. Catharine A. MacKinnon, Toward a Feminist Theory of the State 179-80 (Harvard 1989) ("Women who charge rape say they were raped twice, the second time in court. Under a male state, the boundary violation, humiliation, and indignity of being a public sexual spectacle makes this more than a figure of speech."). See also Dusky, Still Unequal at 389 (cited in note 6) (quoting Alan Dershowitz on the defense of William Kennedy Smith for rape: "The strategy will be to make the woman sorry she ever brought the charges"); National Victim Center, Rape in America at 5 (cited in note 5) (reporting that 68 percent of victims said they were somewhat or extremely concerned about others knowing they had been raped, 50 percent were concerned about their name being made public, and 69 percent were concerned about being blamed by others); Evaluation/Policy Research Associates, A Study of Rape and the Rape Victim for the Chicago-Cook County Criminal Justice Commission 20 (Dec 19, 1977) ("[Some victims] are particularly concerned about how their family and friends will react and even want to hide the event from the family .... Victims may also be concerned about whether they can go through with the [investigatory] process and be able to recount the facts.").

${ }^{21}$ National Victim Center, Rape in America at 10 (cited in note 5) (reporting that 92 percent of rape victims in survey would be less likely to report a rape if they believed their name would be disclosed to the media). 
and perhaps needled by subtle threats from the defendant ${ }^{22}$-may settle and forego the benefits of postponement.

\section{Promotion of False Accusations}

Historically, courts and legal scholars have been particularly sensitive to fears of false accusations of rape. ${ }^{23}$ Courts feared that women would allege rape out of spite or to conceal illicit liaisons. ${ }^{24}$ Some studies have found anecdotal accounts of false accusations, ${ }^{25}$ but there is little empirical support for the proposition that false accusations make up a substantial percentage of rape complaints. ${ }^{26}$

Pretrial settlement may encourage false accusations of rape. A complainant, motivated by spite or greed, may falsely accuse the defendant of rape in order to extort a settlement from him. ${ }^{27}$ A few cases lend support to the hypothesis that some rape complaints are motivated by a scheme to extort money from an innocent defendant. ${ }^{28}$

22 Consider the not-so-subtle threats by the defendant in Lichens $v$ Superior Court, 181 Cal App 2d 573, 5 Cal Rptr 539, 541 (1960): if there was a trial, the victim's "sister's and her mother's names would be dragged into the papers and [] a general 'stink' about the whole thing would be stirred up."

${ }^{3}$ Schulhofer, Unwanted Sex at 17-29 (cited in note 18) (stating that one of the traditional concerns about rape prosecutions was the supposed ease with which false accusations of rape could be made); Matthew Hale, 1 History of the Pleas of the Crown 635 (1778) (asserting that rape charges are "easily to be made and hard to be proved, and harder to be defended by the party accused, tho never so innocent").

2N Marsh, Geist and Caplan, Rape and the Limits of Law Reform at 92 (cited in note 3) (relating examples given by police officers of situations that give rise to false reports of sexual assault: juveniles with truancy records who "mak [e] [up] rape report[s] to cover up the real reason for [their] absence," "married women who are running around ... [who cry] 'rape' when [their] husband[s] find[] out," and "young women who "cry rape' when parents discover them to be sexually active"); Richard A. Posner, Sex and Reason 388 (Harvard 1992) (mentioning reasons for false accusations, including to explain a pregnancy or to gain advantage in a divorce by claiming marital rape).

${ }^{2}$ See, for example, Marsh, Geist and Kaplan, Rape and the Limits of Law Reform at 92 (cited in note 3 ) (describing accounts by police officers).

${ }^{36}$ See Dusky, Still Unequal at 383 (cited in note 6) ("We don't know with any certainty what the number of false accusations are, or how many of those ever go to trial, but one study from the Portland, Oregon, police puts the figure at 2 percent, less than false reports for stolen vehicles."); Marsh, Geist and Kaplan, Rape and the Limits of Law Reform at 86 (reporting a Michigan study finding that most police say that less than 10 percent of rape reports are "unfounded").

"See generally Juan Cardenas, The Crime Victim in the Prosecutorial Process, 9 Harv $J \mathrm{~L} \&$ Pub Pol 357, 362 (1986) (noting that the historical shift from private prosecutions to state prosecutions was partly a response to "initiation of prosecutions for revenge and personal animosity").

23 In United States $v$ Reed, 715 F2d 870, 872 (5th Cir 1983) (per curiam), defendant Burton accused Wolfe of raping her. Wolfe denied the accusation. Id. Defendant Reed contacted Wolfe, saying that the alleged victim's "two big bad brothers in California' would come ... and 'get' Wolfe, but that [] Reed could probably help Wolfe if Wolfe came up with 
A false accuser's ability to extort money from the defendant is greatest before the criminal trial. The accuser can free-ride off the investigative efforts of the state while using the threat of a criminal trial as leverage against the defendant. The defendant faces the prospect of two trials-criminal and civil-and the media coverage that often accompanies a criminal trial. Just as the bona fide rape victim may feel coerced by the threat of stigma to settle, the falsely accused rape defendant may feel compelled to settle to avoid the stigma of a public trial.

\section{Pretrial Settlements Conceal the Rape Problem}

By punishing certain actions, the criminal law educates society about what behavior is unacceptable. ${ }^{29}$ Every pretrial settlement that results in charges being dropped conceals another rapist from the public eye. ${ }^{30}$ Because pretrial settlement requires money, wealthier defendants disproportionately may be able to evade prosecution. Certain types of rapes-such as acquaintance rapes by college students or professionals-will generally involve wealthier defendants. Consequently, those types of rape will receive less prosecutorial attention, thereby perpetuating the myth that the typical rapist is an indigent stranger. ${ }^{31}$

some money." Id. The court affirmed defendants' convictions for extortion of money from the alleged rapist Wolfe "[a]lthough the defendants contend[ed] that they were pursuing what they believed to be a legitimate civil settlement of Burton's claim against Wolfe." Id

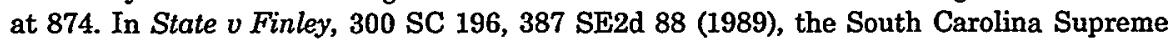
Court reversed a defendant's conviction for sexual assault on the basis of improper evidentiary rulings by the trial court. The court held that the trial court must admit impeachment evidence that the alleged victim was trying to extort money from the defendant by offering to drop the charges. 387 SE2d at 89.90 .

20 See Johannes Andenaes, The General Preventive Effects of Punishment, $114 \mathrm{U} \mathrm{Pa} \mathrm{L}$ Rev 949, 949 (1966) ("By means of the criminal law . . . 'messages' are sent to members of a society .... The decisions of the courts ... transmit knowledge about the law ... [securing] a general preventive effect.").

${ }^{30}$ Very few rapists are subject to the visible public scrutiny of trial. Only a small fraction of rapes end in conviction. See note 10. Further, most convictions are the product of plea bargains. See note 128 .

31 Rape is most often visualized as an attack by a stranger. See Gordon and Riger, The Female Fear at 25 (cited in note 6) ("Most women think most rapes are 'stranger' rapes."). See also MacKinnon, Toward a Feminist Theory of the State at 181 (cited in note 20) ("[R]ape comes to mean a strange (read Black) man who does not know his victim but does know she does not want sex with him, going ahead anyway."). In reality, however, most rapes are committed by men known to their victims. National Victim Center, Rape in America at 4 (cited in note 5) (finding only 22 percent of all rape victims surveyed were assaulted by strangers); Waldron, et al, Sexual Assault in Massachusetts at 10 (cited in note 8) (reporting that 18 percent of surveyed victims were raped by a stranger); MacKinnon, Toward a Feminist Theory of the State at 176 ("Women . . . are most often raped by men whom they know.") (citing studies). 
By concealing cases of acquaintance rape, pretrial settlement perpetuates societal misperceptions of the incidence of rape. Two consequences follow. First, victims of acquaintance rape may feel alienated and hopeless because their experience appears unusual and is not criminally punished..$^{32}$ This, in turn, reduces reporting of rapes, perpetuating societal misperception of the incidence of rape. ${ }^{33}$ Second, many men who do not commit rape in the archetypal fashion may not realize that they are committing a crime. ${ }^{34}$

\section{E. Deterrence of Rape}

Civil settlement undermines the criminal law objectives of deterring and incapacitating rapists. ${ }^{35}$ Theoretically, the com-

\$2 Consider National Victim Center, Rape in America at 7 (cited in note 5) (rape victims suffer much higher rates of depression, drug use, and attempted suicide than do nonvictims of crime).

${ }^{30}$ Gordon and Riger, The Female Fear at 27 (cited in note 6) ("D]ate-rape victims often feel they won't be believed ... and, therefore, there is no point in reporting [the rape]."). Consider the following comparison, made in connection with a story about a woman who told a friend, "I'm not sure, but I think I've been raped," after a man forced himself on her when she changed her mind about going to the man's apartment:

How does it happen that a woman comes to such a tentative conclusion about herself as a victim of a violent crime? People don't come home to find the locks torn off their doors and their belongings strewn all over and say: I'm not sure, but I think our house [has] been broken into.

Diane Mason, Navigating the Dark Ages of Rape, St Petersburg Times ID (Dec 4, 1990).

${ }^{3}$ As Gordon and Riger explain:

[R]esearchers argue that campus rape may be so prevalent because of norms in our society that condone sexual violence. People are conditioned to accept sexual roles in which male aggression is an acceptable part of our modern courtship culture. According to this line of reasoning, campus rapists are ordinary males operating in an ordinary social context, not even knowing they are doing something wrong, let alone against the law.

Gordon and Riger, The Female Fear at 28 (cited in note 6). See also Waldron, et al, Sexual Assault in Massachusetts at 48 (cited in note 8) (citing a study of college students that found "one out of twelve male students reported behavior that met legal rape or attempted rape standards, but none of the same students identified themselves as rapists," and citing a survey of adolescents showing that 20 percent or more believed that forced sex was justified in certain situations). Catharine MacKinnon has argued:

Many women are raped by men who know the meaning of their acts to their victims perfectly well and proceed anyway. But women are also violated every day by men who have no idea of the meaning of their acts to the women. To them it is sex. Therefore, to the law it is sex.... Men set sexual mores ideologically and behaviorally, define rape as they imagine women to be sexually violated through distinguishing that from their image of what they normally do, and sit in judgment in most accusations of sex crimes.

MacKinnon, Toward a Feminist Theory of the State at 180-81 (cited in note 20) (internal citation omitted).

${ }^{*}$ See generally Edmund L. Pincoffs, The Rationale of Legal Punishment (Humanities 1966) (assessing the traditional rationales for criminal punishment: retribution and deterrence). Consider Lobsenz, 15 Crim L Bull at 301-02 (cited in note 16) (conceptualizing criminal law (as distinct from tort) as a sort of class action on behalf of potential future 
plainant could use the threat of criminal sanctions to win a civil settlement equal in amount to the monetary value to the defendant of the expected civil and criminal penalties the defendant faces. If this were the case, civil settlement would not reduce the deterrent effect of criminal law.

In reality, pretrial settlements are unlikely to deter adequately. If the punishment for convicted rapists represents the social judgment of the amount of punishment necessary to deter the defendant, then pretrial settlement will deter adequately only if the defendant is forced to settle for an amount equal to the monetary value of the expected disutility to the defendant of trial and punishment ("optimal amount"). Since the complainant can always refuse to settle and thereby send the defendant to trial (or plea bargain), a complainant seeking to maximize the settlement should be able to negotiate a settlement with the defendant for the optimal amount. ${ }^{36}$ However, this ideal situation is unlikely to occur. The complainant's unwillingness to go to trial and her desire to avoid the trauma of testifying weaken her bargaining position and affect her ability credibly to threaten the defendant with trial if he fails to settle for the optimal amount. The defendant will be able to settle for less than the optimal amount. And since rape defendants as a group can expect to settle for less than the optimal amount, they will be underdeterred from committing rapes. ${ }^{37}$

In addition, pretrial settlement reduces the prosecutor's incentive to investigate allegations of rape. If a complainant can withdraw her participation in the investigation after a settlement, prosecutors will be less likely to invest resources in gathering evidence that they will never use. ${ }^{38}$

victims for injunction, usually in the form of imprisonment). The analysis in the text applies to both specific and general deterrence.

${ }^{36}$ Subject to any possible strategic posturing due to the fact that this negotiation involves a bilateral monopoly. Bilateral monopoly occurs when neither side of a potential transaction can make the transaction with any other party. Because neither side faces competition, the outcome of the negotiations is uncertain. For example, the defendant could lower the settlement amount if he could convince the complainant he would be willing to go to trial if the settlement demand is above some arbitrarily low amount. But, for the reasons described in the text, it is doubtful such a bluff would be effective, given the stakes involved.

${ }^{37}$ Note that if the defendant does not settle, a plea bargain is much more likely than conviction at trial. Although a plea bargain also involves negotiation with the threat of a trial in the background, a plea bargain is more likely to deter the optimal amount. Since the prosecutor seeks convictions and long sentences, and does not fear going to trial, she will be able to threaten trial credibly if the defendant does not plea for a punishment equal to the expected punishment he would receive at trial.

${ }^{33}$ See note 135. 


\section{F. Commodification of Rape and Criminal Sanctions}

Perhaps the most viscerally objectionable quality of pretrial settlement is that it can be characterized as the defendant paying his victim for the rape. In this respect, pretrial settlement may commodify rape. ${ }^{39}$

Commodification occurs when something previously not thought of in terms of monetary value, such as love or a human organ, is exchanged for money or described using market rhetoric. ${ }^{40}$ Commodification can be harmful because it molds social meaning. ${ }^{41}$ A rape "market" makes us "feel discomfort or even insult, and we feel degradation or even loss of the value involved, when bodily integrity is conceived of as a fungible object.".42

Pretrial settlement may commodify rape in two distinct ways. Broadly, pretrial settlement commodifies rape because a rapist can "pay" for a rape after the fact. Rape is not commodified completely because individuals cannot buy and sell rape before the fact, ${ }^{43}$ but settlement (and civil litigation generally) creates an imperfect market in which the rape is legitimized, after the fact, for a price. Under this view, complete noncommodification of rape would entail barring all payments of money damages in every civil rape case. Settlements paid before, or in lieu of, criminal trials are most conducive to rape's commodification because they preclude the imposition of nonmonetary sanctions for rape.

Narrowly, pretrial settlement commodifies rape punishment by assigning a price to nonmonetary sanctions like stigma and incarceration. In this context, pretrial settlement can create the perception of the state promoting commodification. By displacing criminal remedies with monetary payments, pretrial settlement makes rape punishment more like remedies for tort than punishment for crime ${ }^{44}$ weakening the social judgment of the seriousness of rape. Commodification of punishment may undermine

${ }^{39}$ Of course, some scholars argue that commodification is not socially harmful. See, for example, Richard A. Posner, The Economics of Justice 115 (Harvard 1981); Elizabeth M. Landes and Richard A. Posner, The Economics of the Baby Shortage, $7 \mathrm{~J}$ Legal Stud 323 (1978). See also Margaret Jane Radin, Market-Inalienability, 100 Harv L Rev 1849, 1857$58 \mathrm{n} 38$ (1987) (describing the "universal commodification" approach of the scholarship of Richard Posner and Gary Becker).

to Radin, 100 Harv L Rev at 1855 n 24, 1859 (cited in note 39) (defining the term "commodity").

"See id at 1877-87 (discussing the flaws of commodification: "risk of error," "injury to personhood," and transformation of the "texture of the human world").

${ }^{42}$ Id at 1881. Radin goes on to argue that a market for rape "implicitly [] assume[s] that raping 'benefits' rapists. Only an inferior conception of human flourishing would regard rape as benefiting the rapist." Id at 1884 .

${ }^{3}$ By definition, rape is nonconsensual and thus cannot be agreed upon ex ante.

14 See note 35 . 
the social significance and opprobrium attached to imprisonment. ${ }^{45}$

\section{THE LAW REGULATING INFLUENCE OVER VICTIMS AND WITNESSES}

\section{A. Tampering Statutes}

Various state statutes prohibit defendants and potential defendants from using persuasion, money, threats, deceit, or force to influence the conduct of witnesses and victims before and during criminal investigations and prosecutions. ${ }^{46}$

Most states have statutes that prohibit influencing a witness's testimony. At least thirty-four states and the District of Columbia explicitly forbid an offer of money, a "benefit," or anything of value to a witness with intent to influence her testimony or attendance at trial. ${ }^{47}$ At least twenty-seven states and the District of Columbia prohibit attempts to induce false testimony, withholding of testimony, or nonattendance at trial ${ }^{48}$ that do not

*s Of course, the state commodifies the punishment for many crimes by imposing fines. Rape, however, has traditionally been punished by imprisonment (or death). See generally Coker $v$ Georgia, 433 US 584, 593, 597-98 (1977) (striking down death penalty for rape of an adult woman).

${ }^{4}$ States have enacted these statutes under a dizzying array of titles. Section headings include acceding to corruption, bribing a witness, communicating with jurors and witnesses, compounding a crime, indirect contempt, influencing testimony, influencing witness, interference with official proceedings, intimidating a witness, obstruction of justice, retaliation against a witness or victim, tampering with witnesses, and threatening witnesses. Despite the vast array of names, the substance of these statutes varies very little from state to state. Because of this substantive similarity, this Comment refers to the portions of these statutes that prohibit payments to victim-witnesses collectively as "tampering statutes."

${ }^{47}$ Codifications usually refer to this as bribing, influencing, or tampering with a witness. See Ala Code § 13A-10-121 (Michie 1994); Alaska Stat § 11.56.510(2) (1998); Ariz Rev Stat Ann § 13-2802 (West 1989); Ark Code Ann § 5-53-108 (1997); Cal Penal Code $\S \S$ 137(a), 138(a) (West 1988); Colo Rev Stat Ann $\S 18-8-703$ (West 1990); Conn Gen Stat Ann $\S 53 a-149$ (West 1994); 11 Del Code Ann $\S 1261$ (1995); DC Code $\S 22-713(a)(1)$ (1996); Fla Stat Ann § 914.22 (West 1996); Ga Code Ann § 16-10-93(a) (Michie 1996 \& Supp 1998); Hawaii Rev Stat § 710-1070(1) (1993); Idaho Code § 18-2605 (1997); 720 ILCS $\S \S 5 / 32-4,33-1(a)-(b)$ (1998) (formerly Ill Rev Stat ch 38, II 32-4, 33-1(a)-(b)); Ind Code $\S 34-4-7-4$ (1988); Iowa Code Ann $\S \S 720.4,722.1$ (West 1993); Ky Rev Stat Ann $§ 524.020$ (1985); 17-A Me Rev Stat Ann $\S$ 454.1.B (1983 \& Supp 1998); Mass Ann Laws ch 268, § 13B (Law Co-op 1992 \& Supp 1999); Minn Stat Ann § 609.42 subd 1(3) (West 1987); Mo Ann Stat § 575.270.1(3) (Vernon 1995 \& Supp 1999); Neb Rev Stat § 28-918(1) (1995); Nev Rev Stat § 199.240 (1997); NM Stat Ann § 30-24-3A(1) (1994 \& Supp 1998); 1999 NY Laws 215.00; ND Cent Code § 12.1-09-01.1 (1997); Ohio Rev Code Ann § 2921.02(C) (Baldwin 1997); Or Rev Stat § 162.265 (1997); RI Gen Laws § 11-7-11 (1994); SD Cod Laws § 22-1119 (1998); Tenn Code Ann § 39-16-107(a)(1) (1997); Tex Penal Code Ann $\S 36.05(a)$ (Vernon 1994 \& Supp 1999); Va Code $§ 18.2-441.1$ (1996); Wis Stat Ann § 946.61(1)(a) (West 1996); Wyo Stat Ann § 6-5-102(a)(i) (1997).

${ }^{48}$ Unlike most statutes prohibiting payments to witnesses, statutes prohibiting other 
involve payments, threats, fraud, or force.$^{49}$ At least thirty-eight states and the District of Columbia forbid the use of threats or force against a witness with intent to influence her testimony or attendance..$^{50}$ At least twenty-nine states and the District of Columbia prohibit witnesses from accepting or soliciting money with intent to have their testimony or attendance influenced. ${ }^{51}$

non-violent inducements do not bar influencing a witness to give truthful testimony.

${ }^{49}$ This crime is most often called tampering with a witness. See Ala Code $\S 13 \mathrm{~A}-10$ 124 (Michie 1994); Alaska Stat $\S$ 11.56.540, 545 (1998); Ariz Rev Stat Ann § 13-2804 (West 1989); Ark Code Ann § 5-53-110 (1997); Cal Penal Code §§ 136.1(a), 137(c) (West 1988 \& Supp 1999); Colo Rev Stat Ann § 18-8-707 (West 1990); Conn Gen Stat Ann § 53a151 (West 1994); 11 Del Code Ann § 1263(1) (1995); DC Code § 22-722(a)(2)-(3)(A) (1996); Fla Stat Ann § 914.22(2)(a)-(d); Hawaii Rev Stat § 710-1072 (1993); Idaho Code § 18-2604 (1997); 720 ILCS § 5/32-4(a); Ind Code § 34-4-7-4; Kan Stat Ann § 21-3832(a)(1) (1995); Ky Rev Stat Ann § 524.050 (1985); 17-A Me Rev Stat Ann § 454.1.A (1983 \& Supp 1998); Md Ann Code Art 27, § 26 (1996); Mo Ann Stat § 575.270.1(2)-(3) (Vernon 1995 \& Supp 1999); Mont Code Ann § 45-7-206 (1997); Neb Rev Stat § 28-919 (1995); Nev Rev Stat § 199.230 (1997); NJ Stat Ann § 2C:28-5a (West 1995); 1999 NY Laws 215.10; Or Rev Stat § 162.285 (1997); Utah Code Ann § 76-8-508(1) (1995); 13 Vt Stat Ann § 3015 (Equity 1998); Wash Rev Code Ann § 91A.72.120 (West 1998).

${ }^{\text {so }}$ These sections are often labeled intimidating a witness. See Ala Code $\S 13 \mathrm{~A}-10-123$ (Michie 1997); Alaska Stat § 11.56.510(1) (1998); Ariz Rev Stat Ann § 13-2802; Ark Code Ann $\S$ 5-53-109 (1997); Cal Penal Code $\S 137(b)$ (West 1998); Colo Rev Stat Ann §§ 18-8704, 705 (West 1990 \& 1998 Supp); 11 Del Code Ann § 1263(2)-(3) (1995); DC Code § 22722(a)(2)-(3)(A); Fla Stat Ann § 914.22(1)(a)-(f); Ga Code Ann § 16-10-93 (Michie 1996 \& Supp 1998); Hawaii Rev Stat § 710-1071 (1993); Idaho Code § 18-2604; 720 ILCS § 5/324(b); Ind Code §§ 34-4-7-4, 35-44-3-4 (1988); Iowa Code Ann § 720.4; Kan Stat Ann § 213833; Ky Rev Stat Ann § 524.040 (1985 \& Supp 1998); 17-A Me Rev Stat Ann § 454.1.B; Md Ann Code Art 27, § 26; Mass Ann Laws ch 268, § 13B; Minn Stat Ann § 609.498 (West 1997 \& Supp 1999); Miss Code § 97-9-55 (1994); Mo Ann Stat § 575.270.1(1).(2) (Vernon 1995 \& Supp 1999); Nev Rev Stat § 199.240; NM Stat Ann § 30-24-3A(2) (1994 \& Supp 1998); 1999 NY Laws 215.11-13, 15-17; NC Gen Stat Ann § 14-226 (Michie 1993); ND Cent Code § 12.1-09-01.1; Ohio Rev Code Ann §§ 2921.03-04 (Baldwin 1997); $18 \mathrm{~Pa}$ Cons Stat Ann § 4952 (Purdon 1983); RI Gen Laws § 11-32-5 (1994); SC Code Ann § 16-9-340 (1985 \& Supp 1998); SD Cod Laws § 22-11-19; Tex Penal Code Ann § 36.06(a)(2) (Vernon 1994 \& Supp 1999); 13 Vt Stat Ann § 3015; Va Code § 18.2-460 (1996); Wash Rev Code Ann $\S$ 9A.72.110 (West 1998); Wis Stat Ann $\S \S 940.42-45$ (West 1996 \& Supp 1998); Wyo Stat Ann $\S 6-5-305$ (1997).

${ }^{81}$ See Ala Code § 13A-10-122 (Michie 1994); Alaska Stat § 11.56.520 (1998); Ariz Rev Stat Ann § 13.2803 (West 1989); Cal Penal Code $§ 138(b)$ (West 1998); Colo Rev Stat Ann $\S$ 18-8-603 (West 1990); Conn Gen Stat Ann § 53a-150 (West 1994); 11 Del Code Ann $\S 1262$ (1995); DC Code § 22-713(a)(2) (1996); Ga Code Ann § 16-10-92 (1996); Hawaii Rev Stat § 710-1070(2) (1993); Idaho Code § 18-2606 (1997); 720 ILCS § 5/33-1(d)-(e) (formerly Ill Rev Stat ch 38, ๆ 33-1(d).(e)); Iowa Code Ann § 722.2 (West 1993); Ky Rev Stat Ann $\S 524.030$ (1985); 17-A Me Rev Stat Ann $\S$ 454.1.C (1983 \& Supp 1998); Minn Stat Ann $\S 609.42$ subd 1(4) (West 1997); Mo Ann Stat § 575.280(2) (Vernon 1995); Neb Rev Stat $\S$ 28-918(3) (1995); Nev Rev Stat § 199.250 (1997); NJ Stat Ann § 2C:28-5c (West 1995); 1999 NY Laws 215.05; ND Cent Code $\S$ 12.1-09-01.2 (1997); Ohio Rev Code Ann $\S 2921.02(D)$ (Baldwin 1997); Or Rev Stat § 162.275 (1997); 18 Pa Cons Stat Ann § 4909 (Purdon-1983 \& Supp 1998); RI Gen Laws § 11-7-11; SD Cod Laws § 22-11-20 (1998); Tenn Code Ann § 39-16-107(a)(2) (1997); Utah Code Ann § 76-8-508(2)(b) (1995); Wis Stat Ann § 946.61(1)(b) (West 1996 \& Supp 1998); Wyo Stat Ann § 6-5-102(a)(ii) (1997). 
Some states also prohibit influencing a victim's decision to press charges. At least twelve states and the District of Columbia bar dissuading a victim from filing a complaint or otherwise pursuing prosecution. ${ }^{52}$ At least twenty-five states prohibit the acceptance of money not to seek prosecution. ${ }^{53}$ Significantly, several of those states provide, by statute, an affirmative defense that the payment made to dissuade the victim from prosecuting does not exceed the amount reasonably due to the victim as restitution. ${ }^{54}$ Finally, a few states explicitly authorize the court to enjoin the defendant from violating tampering statutes or otherwise communicating with the victim..$^{55}$

\section{B. The Scope of Tampering Statutes}

Tampering statutes and statutes barring the use of threats and force against a witness or victim reach many possible interactions between defendants and complainants. ${ }^{56}$ These statutes

${ }^{32}$ See Cal Penal Code $\S 136.1(b)$ (West 1988 \& Supp 1999); DC Code $\S 22-722(a)(3)$ (1996); Fla Stat Ann § 914.22; Ga Code Ann § 16-10-92; 720 ILCS §5/32-1 (formerly Ill Rev Stat ch 38, I 32-1); Ky Rev Stat Ann § 519.030(1)(b) (1985); 17-A Me Rev Stat Ann § 754.1.A (1983 \& Supp 1998); Mo Ann Stat § 575.270.1(3); NJ Stat Ann § 2C:29.4 (West 1995); NM Stat Ann § 30-24-3A(3) (1994); 1999 NY Laws 215.45.1(b); SD Cod Laws § 2211-10 (1998); Tex Penal Code Ann § 36.05(a)(5).

${ }^{83}$ This crime is almost universally termed compounding. See Hawaii Rev Stat $\S 710$ 1013 (1993); 720 ILCS §5/32-1; Iowa Code Ann § 720.1 (West 1993); Kan Stat Ann § 213807; Ky Rev Stat Ann § 519.030 (1985); Mass Ann Laws ch 268, § 36 (Law Co-op 1992); 17-A Me Rev Stat Ann 754.1.B (1983 \& Supp 1998); Mich Comp Laws Ann § 750.149 (West 1991); Minn Stat Ann § 609.42 subd 1(5) (West 1987); Miss Code Ann §§ 97-9-7, 9 (1994); Mont Code Ann § 45-7-305; Nev Rev Stat § 199.290; NJ Stat Ann § 2C:29-4; NM Stat Ann §§ 30-22-6, 30-24-3.1A(2) (1994); 1999 NY Laws 215.45; Ohio Rev Code Ann $\S 2921.21$ (Baldwin 1997); 21 Okla Stat Ann §§ 543-44 (West 1983 \& Supp 1999); Or Rev Stat § 162.335; 18 Pa Cons Stat Ann § 5108 (Purdon 1983 \& Supp 1998); SC Code Ann $\S$ 16-9-370 (1985); SD Cod Laws § 22-11-10; Tenn Code Ann § 39-16-604 (1997); Va Code $\S 18.2-462$ (1996); Wis Stat Ann § 946.67 (West 1996 \& Supp 1998); Wyo Stat Ann § 6-5203 (1997).

it These statutes suggest that legislatures have considered the application of tampering laws to payments that would satisfy civil claims. Some legislatures have made the judgment that some such payments should not be illegal. See 17-A Me Rev Stat Ann § 754.3.B (1983); NJ Stat Ann § 2C:29.4; 1999 NY Laws 215.45.2; ND Cent Code § 12.109-01.3.b (1997); SD Cod Laws § 22-11-11; Tenn Code Ann § 39-16-604(c); Texas Penal Code Ann § 36.05(c) (Vernon 1994); Wis Stat Ann §§ 946.61(2), 67(2) (West 1996 \& Supp 1998).

${ }^{\text {ss }}$ See Cal Penal Code $\S 136.2$ (West 1988 \& Supp 1999); Kan Stat Ann $\S 21-3834$ (1995); NJ Stat Ann § 2C:28-5.1 (West 1995).

${ }^{56}$ Tampering statutes are written in inclusive terms like "induce" or "influence." See, for example, Cal Penal Code $\S 137$ (c) ("Every person who knowingly induces another person to give false testimony [or material information] or withhold true testimony [or material information] is guilty of [tampering]."); Idaho Code $\S 18-2604$ ("Any person who ... by any manner willfully [] influences, impedes, deters ... or prevents a witness ... from testifying freely, fully, and truthfully ... is guilty of [intimidation]."). 
prohibit offers or payments of money ${ }^{57}$ and the use of threats, force, harassment, ${ }^{58}$ or even verbal persuasion ${ }^{59}$ to affect the victim's conduct vis-à-vis the potential prosecution. In fact, defendants have attacked (unsuccessfully) similarly worded bribery statutes on the constitutional grounds of overbreadth and vagueness. ${ }^{60}$

Courts have construed the purposes and functions of tampering statutes broadly to prevent the miscarriage or subversion of justice. For example, the Supreme Court of Colorado described a tampering statute as "protect[ing] against conduct which would threaten the veracity and cooperation of witnesses by prohibiting any attempt to induce another to testify falsely or otherwise subvert the administration of justice."61 The New York Court of Appeals characterized the purpose of a bribery statute as "to guard against corrupt interference with the judicial system" and "against subversion of judicial proceedings by suppressing needed evidence." ${ }^{\prime 2}$ And a Washington state court emphasized the connection between tampering statutes and the enforcement of criminal laws, concluding: "Witness tampering is an offense against the very object for which the courts are established. . . . There is a direct, elemental nexus between the act of tampering and the underlying crime." ${ }^{33}$ Thus, witness tampering statutes serve as a sort of meta-criminal law, enforcement of which enables the enforcement of the rest of criminal law.

Courts overwhelmingly have given tampering statutes expansive constructions. Courts construe "witness" to include a present or potential witness, regardless of whether a complaint has been filed or proceedings initiated. ${ }^{64} \mathrm{~A}$ person can remain a wit-

${ }^{57}$ See note 47.

ss See note 50.

${ }^{\text {so }}$ See note 49.

${ }^{\infty}$ See, for example, Bachlet $v$ State, 941 P2d 200, 203-06 (Alaska App 1997) (holding that the Alaska statute prohibiting bribery of officials is not unconstitutionally overbroad or vague); State v Greco, 57 Wash App 196, 787 P2d 940, 943 (1990) (holding that the Washington statute prohibiting bribery of officials is not unconstitutionally overbroad since a corrupt intent element is implied, ensuring that no protected activity is punished).

${ }^{61}$ People v Moyer, 670 P2d 785, 791 (Colo 1983) (construing Colo Rev Stat Ann § 18-8605, CRS 1973 (1978 Repl Vol 8), repealed, replaced by Colo Rev Stat § 18-8-707).

${ }^{2}$ People v Bell, 73 NY2d 153, 535 NE2d 1294, 1299-1300 (1989) (construing what is now 1999 NY Laws $§ 215.00$, bribing a witness). See also Staggs $v$ State, 53 Ala App 314, 299 S2d 756, 766 (1974) (stating that the purpose of bribery statutes is "to prevent miscarriages of justice"), quoting Wilson v United States, 77 F2d 236, 240 (8th Cir 1935).

${ }^{\infty}$ State $v$ Sanders, 66 Wash App 878, 833 P2d 452, 455 (1992) (construing Wash Rev Code Ann § 9A.72.120(1)).

" See, for example, Bell, 535 NE2d at 1300 ("[A]n individual's status as a witness depends upon the evidence he can supply the court, not the immediacy of the need for the evidence."); State v DeKay, 387 S2d 570, 572-73 (La 1980) (rejecting the argument that 
ness after conviction of the defendant, ${ }^{65}$ and can be a "victim" even if the underlying crime is considered "victimless." dant can be convicted of obstruction of justice, even if he never communicates his threat to the witness and the witness never hears of the threat. ${ }^{67}$ An offer of a bribe is sufficient for conviction, even if the offer is not accepted and does not influence the witness. ${ }^{68}$ It may not even be necessary to prove that the witness or victim understood the offer to be corrupt. ${ }^{69}$ When the statute is not limited explicitly to inducing false testimony, "influence" may include payments for true testimony or for withholding testimony. ${ }^{70}$

Against this general interpretive backdrop, courts sometimes face cases where the defendant intends to influence the bringing of charges, rather than testimony at trial. When the influence is in the form of threats or violence, courts have not deviated from

victims were not witnesses because they had not yet been subpoenaed); State $v$ Crider, 21 Ohio App 3d 268, 487 NE2d 911, 913 (1984) ("It would be ludicrous to hold that the victim, who was intimidated, is not a 'witness' . . . because the victim has not yet had the opportunity to identify the offender, the prosecution had not issued a complaint against him, or the police had not yet apprehended him to commence proceedings.").

${ }^{\infty}$ Smith $v$ State, 902 P2d 1271, 1279 (Wyo 1995) (holding that the witness retained status, under a federal obstruction of justice statute, while the case was on direct appeal).

${ }^{\circ}$ State $v$ Vinje, 201 Wis 2d 98, 548 NW2d 118, 120-21 (Wis App 1996) (holding that wife was "victim" of husband's "disorderly conduct").

${ }^{67}$ Irving $v$ United States, 673 A2d 1284, 1289 (DC App 1996) (holding defendants uncompleted endeavor to have a witness murdered sufficient to constitute the offense of obstruction of justice under DC Code $§ 22-722$ (a) (Supp 1995) because his actions demonstrated the requisite mental state).

${ }^{68}$ See, for example, Moyer, 670 P2d at 791 ("Under the tampering statute, it is not necessary that the defendant succeed in his attempt or actually induce the witness to do anything."); People v Sajous, 173 Misc 2d 55, 661 NYS2d 488, 490 (Dist Ct 1997) (“[Tampering with a witness] is committed if the attempt is made and regardless of whether or not it is successful.").

${ }^{6}$ See Staggs, 299 S2d at 764 ("What is meant by 'upon any understanding or agreement that the testimony of such witness shall be thereby influenced' is that such is the condition upon which the offer, gift or promise is made ... . A rejection [does not erase] the criminal act."). Compare Martinez v State, 696 SW2d 930, 932-33 (Tex App 1985) ("Common sense dictates that when it is alleged and proved that the defendant offered or solicited a proscribed benefit, it is not necessary to further prove that the offer or solicitation resulted in a bilateral arrangement or unlawful contract with the other party."), and Hubbard $v$ State, 668 SW2d 419, 420-21 (Tex App 1984) ("The offense [of bribe giving or receiving] focuses on the mental state of the actor, and is complete if [the actor] . . . intends an agreement."), with McCallum v State, 686 SW2d 132, 136 (Tex Crim App 1985) (holding that when indictment alleged a completed bribe, there must be a "bilateral agreement" between the parties). Note that these Texas cases all involved bribery of public officials rather than witnesses.

${ }^{\text {to }}$ See People v Gliksman, $78 \mathrm{Cal}$ App 3d 343, 144 Cal Rptr 451, 455-56 (1978) ("[T]he Legislature, when it used the general term 'influenced,' intended ... [to reach] one who would condition the giving of true testimony upon the payment of a bribe."). But see State $v$ Halleck, 308 NW2d 56, 59 (lowa 1981) ("Merely offering restitution if the witness tells the truth, however, is not prohibited."). 
their broad textual approach to enforcement. ${ }^{71}$ However, when no threats are involved, or when money changes hands, courts do not apply the tampering statutes consistently. Instead, courts take several different approaches to payments-including ostensible settlements-made to a victim to ensure that the victim does not testify or that the charges are dropped.

On one end of the spectrum is Lichens $v$ Superior Court ${ }^{72}$ in which the California Supreme Court construed the state bribery statute narrowly and held that payments made to a victim to drop attempted rape charges did not violate the statute. ${ }^{73}$ The defendant in Lichens approached the complainant's husband offering " $\$ 500$ if the victim would drop the case." When the victim adamantly refused, the defendant contacted the victim and her husband twice more, "stat[ing] that [the victim's] sister's and her mother's names would be dragged into the papers and that a general 'stink' about the whole thing would be stirred up ... . and a lot of people are going to get hurt."75 The court interpreted the statute to require an agreement that the witness not attend trial; paying the victim to drop the charges was not enough to establish a violation. ${ }^{76}$

Following the reasoning of Lichens, some courts declare flatly that 'agreeing to 'drop' charges is certainly not the same as agreeing to alter testimony or absent oneself entirely from a proceeding," as required by most bribery statutes. ${ }^{77}$ One court applied this reasoning in overturning a tampering conviction in which the defendant offered money to the complainant to drop the rape charges and provided the complainant with a memoran-

"See, for example, In re Phillippa P., 221 AD2d 159, 633 NYS2d 287, 288 (1995) (rejecting "argument that [NY Laws $\S 215.15]$ is inapplicable to attempts to coerce a complainant to [drop charges]"); State v James, 88 Wash App 812, 946 P2d 1205, 1207 (1997) (applying Wash Rev Code § 9A.72.110(1) (1985) to criminalize threats made by a person in an attempt to prevent the reporting of a crime).

12181 Cal App 2d 573, 5 Cal Rptr 539 (1960).

${ }^{73} 5$ Cal Rptr at 541-42. The bribery statute read, in relevant part: "[E]very person who attempts by means of any offer of a bribe to dissuade any [witness or person about to be called as a witness] from attending upon any trial, is guilty of a felony." Id.

"Id at 541.

7 Id.

${ }^{76}$ Id.

${ }^{n}$ People $v$ Harper, 75 NY2d 313, 552 NE2d 148, 150 (1990). See also People v Cribas, 231 Cal App 3d 596, 282 Cal Rptr 538, 546 (1991) ("Asking [the complainant] to withdraw the charges is no more the equivalent of influencing her testimony than it is of inducing her not to attend trial."); Sheppard $v$ State, 484 NE2d 984, 988 (Ind App 1985) (construing Ind Code $\S 35-44-3-4$ (1982), and finding that defendant's request to an acquaintance not to pick him out of a lineup did not violate the obstruction of justice statute absent any showing of "coercion" and stating that "criminal statutes are to be strictly construed against the state"). 
dum of "the most important things to remember," which the complainant later testified contained false information. ${ }^{78}$

On the other end of the spectrum, some courts apply tampering statutes aggressively to payments not to prosecute, and even to pretrial settlements. In State $v$ Ali, ${ }^{79}$ the court affirmed a conviction for attempting to bribe a witness where the defendant offered the complainant "a 'tax-free' $\$ 20,000$ settlement . . . in exchange for the victim's decision not to pursue the rape charges." The court rejected the defendant's contention that the offer of payment was like a "suggest[ion] [of] a monetary settlement," stating that the "circumstances surrounding [the defendant's] 'offer of settlement' were highly suspicious." 82

In People $v$ Picl, ${ }^{83}$ the court stated that "no express statement of the purpose of a bribe is needed in order for the factinder to gather ... that the accused sought to persuade a witness to absent himself. ... '[S]uch a solicitation may be in the form of words which carry the import of a bribe and were evidently intended to be so understood." 84 Although the statute's express language prohibited only "any bribe [made] upon any understanding or agreement that the testimony of [the] witness shall be thereby influenced," the court held that "[t]he grand jury had probable cause to believe that defendant intended to influence [complainant's] testimony by way of persuading him to withhold it altogether." 85 The "defendant himself testified that the only act a witness can perform to prevent prosecution in nonmisdemeanor cases is to 'refuse to testify."'86

State $v$ LaPointe, 418 NW2d 49, 50-52 (Iowa 1988) (holding that under a statute prohibiting payments to "improperly influence ... [the witness's] testimony ... or to prevent such person from testifying," offering money to "deter a victim from pursuing criminal charges ... simply is not prohibited by the express terms of [the statute]"). The court's decision was based, in part, on the fact that after the defendant first offered to compensate the victim for her injuries, he never did so again, and the two resumed their prior intimate relationship. Id at 51.

79966 Tenn Crim App LEXIS 617.

so Id at *15-16.

s1 Id at * 15 .

82 Id. See also DeKay, 387 S2d at 572, which involved an offer by a sex offense defendant to "settle the case" with the victims by giving them $\$ 5000$ in exchange for affidavits swearing he committed no wrongdoing. The court upheld the conviction for bribery.

331 Cal 3d 731, 646 P2d 847 (1982). Pic'l arose out of a theft prosecution.

84 646 P2d at 852.

ss Id at 853 (quoting Cal Penal Code $§ 137$ ).

${ }^{86} 646 \mathrm{P} 2 \mathrm{~d}$ at 852. In Halleck, 308 NW2d at 58-59, also involving a theft prosecution, the defendant merely asked the victim to tell the prosecutor that he had received restitution and was not interested in prosecution, but the court inferred that payment of restitution illegally induced the victim's subsequent testimony. 
In addition, courts' construction of tampering statutes may vary according to the amount of overlap between statutes, as is demonstrated by a set of cases from Illinois. ${ }^{87}$ In People $v$ Scrib$n e r,{ }^{88}$ the Illinois Supreme Court held that the communicating with a witness statute, which prohibits an offer of payment to a witness "with intent to deter any [party or] witness from testifying freely, fully and truthfully to any matter pending in any court," ${ }^{19}$ does not apply to a defendant's offer of money to keep a complainant from coming to court. ${ }^{90}$ However, the court stated that the conduct did constitute compounding a crime, a separate offense specifically prohibiting payments "not to prosecute" for which the defendants had not been indicted. ${ }^{92}$ The court concluded, "[W]e do not believe the legislature intended section 32-4 of the Criminal Code [] as a duplicate of section 32-1 of the Code and thus entirely superfluous."

However, in People $v$ Jackson, ${ }^{94}$ an Illinois court construed tampering statutes more broadly in the absence of statutory overlap. Following the reasoning of Scribner, the court dismissed an indictment for communicating with a witness but affirmed a conviction for bribery of a defendant who had offered the alleged assault victim twenty-five dollars to drop charges after the trial had begun. ${ }^{95}$ In Illinois, bribery requires "intent to influence the performance of any act related to the employment or function of any ... witness." ${ }^{96}$ The court held that a jury reasonably could find the payment was intended to influence "the performance of an act related to the function of a witness." ${ }^{\text {97 }}$ This was true, the court noted, even though the complainant would request that the charges be dropped in her role as complainant, not witness. ${ }^{98}$

In sum, when a violation of a tampering statute involves an alleged pretrial settlement, courts have not consistently applied tampering statutes. Worse, there are few cases-and even fewer

\footnotetext{
${ }^{87}$ Like most states, Illinois has numerous statutes prohibiting various forms of tampering. See 720 ILCS $§ \S 5 / 32-1,32-4,33-1(a)$-(b), (d)-(e).

108 Ill App 3d 1138, 440 NE2d 160 (1982).

440 NE2d at 164 (quoting Ill Rev Stat ch 38, If 32-4).

so 440 NE2d at 164.

${ }^{91}$ Ill Rev Stat ch 38, I 32-1, cited in Scribner, 440 NE2d at 164.

${ }^{2}$ Scribner, 440 NE2d at 165.

${ }^{83}$ Id. People $v$ Robinson, 186 Ill App 3d 1, 541 NE2d 1336 (1989), involving a defendant in a sexual assault prosecution, followed Scribner, dismissing communicating with a witness charges when a payment not to testify was not alleged.

94 231 Ill App 3d 801, 596 NE2d 1251 (1992).

${ }^{9} 596$ NE2d at 1251-52.

* Id at 1252 (quoting Ill Rev Stat ch 38, I 33-1(a)).

${ }^{97} 596 \mathrm{NE} 2 \mathrm{~d}$ at 1253 .

Id.
} 
involving rape prosecutions ${ }^{99}$ - to guide future courts. ${ }^{100}$ Thus, it seems that a prosecution of a rape defendant for offering a pretrial settlement in order to induce the victim not to press the prosecution would present difficult, and probably novel, questions in most, if not all, jurisdictions. The reasons for choosing a particular interpretation of tampering statutes in cases involving rape defendants need to be articulated.

\section{HOW COURTS SHOULD INTERPRET TAMPERING STATUTES IN PROSECUTIONS FOR PRETRIAL SETTLLMENT IN RAPE CASES}

Courts should allow the finder of fact to find witness or victim tampering when there is evidence that a pretrial settlement was designed to influence the complainant's participation in the prosecution. Although few reported cases discuss the application of tampering statutes to pretrial settlement, this interpretation of tampering statutes is consistent with the text, purposes, and structure of tampering statutes. ${ }^{101}$ In addition, in rape prosecutions, allowing a finder of fact to infer intent to influence the complainant from the circumstances surrounding the pretrial settlement is consistent with the willingness of courts to draw inferences in cases of alleged intimidation of witnesses.

\section{A. The Statutory Interpretation Argument}

Courts have rarely interpreted tampering statutes in relation to pretrial settlements. ${ }^{102} \mathrm{~A}$ thorough analysis of tampering statutes, however, suggests that courts should review pretrial settlements for violations of tampering statutes. As with all criminal statutes, the interpretation of tampering statutes should look to the text, purposes, and structure of the statutes in order to find the meaning that most makes sense of them. ${ }^{103}$

${ }^{9}$ Lichens, Robinson, Ali, and DeKay are rare examples of such cases. Also, in a pair of unreported Connecticut cases, two attorneys were prosecuted for negotiating a $\$ 10,000$ restitution payment to a rape complainant in an arrangement that involved getting a psychiatrist to prepare a statement saying the trial would be "too traumatic" for the complainant. Etkind, A Hazy, Hazardous Line, Conn L Trib (cited in note 14).

${ }^{100}$ This is almost certainly because pretrial settlement rarely involves prosecutors, and few settlements are subject to prosecutorial scrutiny without the complainant's request. It is likely that most successful attempts to influence the complainant with a pretrial settlement escape review. Consider id (indicating that pretrial settlements and other bargains are "as commonplace as [they are] risky").

${ }^{101}$ As noted above, the texts of most tampering statutes are remarkably similar. Thus, this Comment does not parse the text of particular statutes.

${ }^{102}$ But see Scribner, 440 NE2d at $162-63$ (providing some analysis of two Illinois tampering statutes).

${ }^{100}$ See, for example, Holloway $v$ United States, 119 S Ct 966, 969 (1999) (following the words of the statute and "also its placement and purpose in the statutory scheme"); $M u$ s- 
The analysis begins with the statutory text. ${ }^{104}$ The text should be given its "plain and ordinary meaning"105 and a "commonsense reading." 106 The text of most states' tampering statutes prohibits an offer of money to influence a victim or witness ${ }^{107}$ or to induce a victim not to seek prosecution. ${ }^{108}$ In rape prosecutions, the alleged victim almost inevitably is a witness; thus, the complainant is a "witness" within the ordinary meaning of most tampering statutes-even those that do not apply explicitly to victims. In addition, pretrial settlements can induce complainants not to testify or not to seek prosecution; ${ }^{109}$ the settlements enable

carello $v$ United States, 524 US 125, 118 S Ct 1911, 1914-18 (1998) (looking to the statute's language and evidence of legislative intent, and interpreting the statute to make "sense" of the statutory scheme).

${ }^{104}$ See Holloway, $119 \mathrm{~S}$ Ct at 969; Muscarello, $118 \mathrm{~S}$ Ct at 1914; State $v$ Jason B., 248 Conn 543, 729 A2d 760, 767 (1999) ("We start with the language of the statute.").

${ }^{100}$ Scribner, 440 NE2d at 164.

${ }^{106}$ Holloway, $119 \mathrm{~S} \mathrm{Ct}$ at 970 . "Generally, criminal statutes should be strictly construed. Strict construction, however, does not require that statutes be given the narrowest meaning allowed by the language; rather the language should be given 'a reasonable or common sense construction." State $v$ Jones, 750 P2d 828, 831 (Alaska App 1988). Accord State $v$ Ogden, 118 NM 234, 880 P2d 845, 854 (1994). See also Jones, 750 P2d at 831 ("Common sense should be used to resolve questions of statutory construction when there is little legislative history from which to determine the objectives of the legislature.").

${ }^{107}$ For examples of typical statutes prohibiting payments to influence testimony in states without statutes prohibiting payments not to prosecute, see Ala Code $\S 13 \mathrm{~A}-10$ 124(a) ("A person commits the crime of tampering with a witness if he attempts to induce a witness ... to: (1) Testify falsely or withhold testimony; or (2) Absent himself from any official proceeding to which he has been legally summoned."); Ark Code $\$ 5-53-110$ ("A person commits the offense of tampering if . . . he induces or attempts to induce another person to: (1) Testify or inform falsely; or (2) Withhold any unprivileged testimony [or] information ... or (4) Absent himself from any proceeding or investigation to which he has been summoned."); Colo Rev Stat Ann § 18-8-703 ("A person commits bribing a witness or victim if he offers, confers, or agrees to confer any benefit upon a witness, or a victim ... with intent to: (a) Influence the witness or victim to testify falsely or unlawfully withhold testimony; or ... (c) Induce the witness or victim to absent himself from an official proceeding to which he has been legally summoned."). Note that some statutes apply explicitly to witnesses and victims, and others only to witnesses.

${ }^{100}$ For examples of laws prohibiting payments not to prosecute, see 720 ILCS $\S 5 / 32-$ I(a) ("A person compounds a crime when he ... offers to another any consideration for a promise not to prosecute or aid in the prosecution of an offender."); 1999 NY Laws 215.45(1)(b) ("A person is guilty of compounding a crime when ... [h] confers, or offers or agrees to confer, any benefit upon another person upon an agreement or understanding that such other person will refrain from initiating a prosecution for a crime.").

${ }^{100}$ When the complainant seeks to end the prosecution, this entails, by necessity, seeking not to attend trial and not to testify. Thus, it is irrelevant whether or not a state's tampering statutes prohibit only the influencing of testimony. Since discontinuing prosecution is within the sole discretion of the prosecutor, a complainant may have to refuse to testify in order to convince the prosecutor to dismiss the charges. In People v Cribas, 231 Cal App 3d 596, 282 Cal Rptr 538, 545 (1991), the California Attorney General argued that it "would be ludicrous to conclude that an agreement to get the witness 'to drop' a case does not reasonably mean 'to influence a witness not to testify.' ... [B] [ecause [the complainant has no] authority to dismiss the case, the only way she could drop the charges was by refusing to testify." See also Pic'l, 646 P2d at 852 (noting that the defen- 
complainants to avoid continuing the prosecution and being subject to the humiliation and trauma of testifying about their experiences in court. In light of these facts, common sense compels the conclusion that the statutory text of most tampering statutes applies to pretrial settlements.

Further, penal statutes should be construed "in light of the evil sought to be remedied." 110 Courts have suggested that the purpose of tampering statutes is to prevent obstruction of judicial proceedings. ${ }^{111}$ Because rape defendants can effectively employ pretrial settlement to prevent the initiation or completion of prosecutions, ${ }^{112}$ it would be unfaithful to the purposes of tampering statutes to allow the resolution of civil claims to enable defendants to avoid criminal claims. ${ }^{113}$ Otherwise, pretrial settlement becomes a loophole that defeats the primary purpose of tampering statutes. Given the social cost of foregone rape prosecutions, ${ }^{114}$ closing this loophole is especially important.

The structure of some states' tampering statutes provides additional evidence that it would be prudent to construe tampering statutes to cover pretrial rape settlements as this Comment suggests. Some states provide an affirmative defense to a tampering prosecution if the payment made to get the charges dropped does not exceed the amount reasonably due as restitution. ${ }^{115}$ This indicates that some legislatures intended to protect some pretrial settlements from prosecution for tampering.

dant admitted that refusing to testify was the only way the complainant could fulfill his agreement to do everything in complainant's power to prevent the prosecution).

${ }^{10}$ State $v$ Richard Knutson, Inc, 196 Wis 2d 86, 537 NW2d 420, 423 (1995), citing State $v$ Trimm, 163 Wis $2 d$ 894, 472 NW2d 593, 595 (App 1991). See also Ogden, 880 P2d at 854 ( $[\mathrm{T}]$ he evils sought to be overcome should be given special attention.").

iI See notes 61-63 and accompanying text.

${ }^{112}$ See Part I.A.

${ }^{113}$ This reading employs the commonsense observation that a transaction can be a bribe in substance though perhaps not in form. State $v$ Rempel, 114 Wash 2d 77, 785 P2d 1134,1137 (1990) (" $[\mathrm{A}] \mathrm{n}$ attempt to induce a witness to withhold testimony does not depend only upon the literal meaning of the words used. The State is entitled to rely on the inferential meaning of the words and the context in which they were used."); Picl, 646 P2d at 852 ("[T] he cases have never suggested that the briber must parrot the precise words of the statute in order to perpetrate the offense."); People v Mendoza, 59 Cal App 4th 1333, 69 Cal Rptr 2d 728, 735 (1997) ("There is, of course, no talismanic requirement that a defendant must say 'Don't testify' or words tantamount thereto, in order to commit the charged offenses [a]s long as his words or actions support the inference [of influence].").

"See Part I.D-F.

${ }^{115}$ See note 54 . Notably, two states have begun to require some form of state intervention in pretrial settlements, one by statute and one by judicial decision. Tex Penal Code Ann $\$ 36.05$ (c) (payment of restitution must be negotiated or agreed to by prosecution in order for the defense to apply); People $v$ Anonymous B, 56 Misc 2d 792, 290 NYS2d 507, 511 (1968) (holding that restitution "is to be made subject to and under judicial control and not as part of a bargain to avoid prosecution"). 
In states where legislatures have not spoken on the question of an affirmative defense, however, it is not clear what they would say if they did address the issue. On the one hand, absence of a defense may indicate that the legislature did not believe that pretrial settlements would be reached at all by tampering statutes; thus, there would be no need to include an affirmative defense. On the other hand, given that the affirmative defense exists in some states, the absence of an affirmative defense in other states may indicate a deliberate decision to expose pretrial settlements to prosecution for violation of tampering statutes.

Although it is conceivable that some legislatures intended pretrial settlements made with the intent to influence the complainant to be legal, the text and purpose of tampering statutes lead to a contrary conclusion: that such corrupt pretrial settlement offers violate the law. Further, the fact that some states have enacted an affirmative defense indicates that legislatures are on notice that the broad language of tampering statutes reaches payments that appear to settle civil claims while actually affecting the criminal prosecution. And if some legislatures simply have not considered the application of tampering statutes to these factual situations, then the text and purposes of the statutes alone justify their application to pretrial settlements.

Even if legislative intent is somewhat unclear, prosecution of corrupt pretrial settlements should still be sought, as the prosecutions will serve as an information-eliciting device: if for some reason the legislature did not intend a tampering statute to be as broad as its text indicates, prosecutions for corrupt pretrial settlements will encourage revision of the statute by the legislature to make it more clear. But speculation about legislative intent when the tools of statutory interpretation yield a clear result should not prevent courts from employing the commonsense interpretation of the statute.

Finally, the "rule of lenity" is inapposite. The "rule of lenity" requires that ambiguous criminal statutes be construed against the state. ${ }^{116}$ The rule applies only if, after employing all the tools of statutory construction, the court "can make no more than a guess as to what [the legislature] intended."117 Because an analy-

\footnotetext{
${ }^{116}$ Muscarello, $118 \mathrm{~S}$ Ct at 1919; Ogden, 880 P2d at 853; State $v$ Collins, 580 NW2d 36, 41 (Minn App 1998).

${ }^{117}$ Muscarello, $118 \mathrm{~S} \mathrm{Ct}$ at 1919 ("To invoke the rule, we must conclude that there is a grievous ambiguity or uncertainty in the statute.") (internal quotations omitted); Ogden, $880 \mathrm{P} 2 \mathrm{~d}$ at 853 ("L]enity is reserved for those situations in which a reasonable doubt persists about a statute's intended scope even after resort to the language and structure, legislative history, and motivating policies of the statute.") (internal quotations omitted); $J a$ -
} 
sis of the text, purposes, and structure of tampering laws provides a clear indication of the scope of the statutes, the rule of lenity should not apply to the application of tampering statutes to pretrial settlements for rape. ${ }^{118} \mathrm{~A}$ few cases have held to the contrary, construing tampering statutes narrowly and invoking the principle that "[c]riminal or penal statutes are to be construed strictly in favor of the accused." This is not a correct application of the rule of lenity, which should be used only in the face of unresolvable ambiguity. Not to limit this rule in this manner would reduce the interpretation of criminal statutes to absurdity, "for most statutes are ambiguous to some degree." 120 To the extent these cases stand for narrow construction of tampering laws in spite of their text and purpose, they should not be followed.

\section{B. The Argument that Pretrial Settlement Is Analogous to Intimidation}

Courts have been willing to infer intent to influence a witness or victim in cases involving threats or force by the defendant. ${ }^{121}$ For example, a statement that, on its face, is merely an expression of anger may, in context, create an inference of intent to influence the witness's testimony through implied threats.

Pretrial settlements, unlike outbursts or violence, have a legitimate purpose and are entitled to a presumption of legality; however, like cases involving alleged threats, pretrial settlements during a rape prosecution have great potential to influence the

son $B ., 729$ A2d at 769 ("[W]e ... reserve lenity for those situations in which a reasonable doubt persists about a statute's intended scope even after resort to the language and structure, legislative history, and motivating policies of the statute."), quoting Moskal $v$ United States, 498 US 103, 108 (1990) (internal citations omitted).

${ }^{118}$ One concern that may motivate application of the rule of lenity here is adequate notice to the defendant. The purpose of the rule of lenity "is to ensure that "criminal statutes will provide fair warning concerning conduct considered illegal." Collins, 580 NW2d at 41 (citations ommitted). Because the language of tampering statutes is clearly very broad, there is little danger that a defendant will be unaware that paying someone with intent to prevent the bringing of charges or testimony is illegal. Consider the unreported case described in Smith and Edwards, Paying Off on Sex Crimes (cited in note 1): an attorney was prosecuted for arranging a payment, ostensibly of restitution, to a rape complainant to get the charges dropped. The attorney was recorded counseling his client, "You know you're not allowed to pay someone not to testify. Between you and me, thats what it is, but I prefer to think of it the other way."

${ }^{119}$ Sheppard $v$ State, 484 NE2d 984, 988 (Ind App 1985) (construing Ind Code $\S 35-44-$ 3-4 (obstruction of justice)).

${ }^{120}$ Muscarello, $118 \mathrm{~S}$ Ct at 1919.

${ }^{121}$ For example, the court in Mendoza found the statement that the witness had "fucked up" defendant's brother's testimony with her own and that defendant was "going to talk to some guys from [his street gang]" allowed the jury to infer both the elements of (1) threat of force or violence and (2) attempt to prevent the witness from giving testimony in the future. $69 \mathrm{Cal}$ Rptr $2 d$ at 734. 
complaining witness coercively. No less than threats and violence, pretrial settlement in rape cases should be scrutinized, because a complainant may be particularly vulnerable to pressure from the defendant. ${ }^{122}$ Pretrial settlement provides an avenue through which the defendant can channel his (illegal) payment and coerce the complainant. ${ }^{123}$

Although pretrial settlement may seem innocuous, certain facts may give rise to the inference that the defendant intended to influence the complainant's cooperation with the prosecution. The defendant, for example, can structure a pretrial settlement to deter the complainant from pressing the prosecution. ${ }^{124}$ Evidence of harassment of the complainant, ${ }^{125}$ concealment of negotiations from authorities, ${ }^{126}$ or efforts to remove the complainant from the jurisdiction ${ }^{127}$ during or subsequent to settlement could inculpate a defendant. Courts faced with an allegedly corrupt pretrial settlement should be willing to draw inferences of criminal intent, just as a court reviewing alleged threats would, when the facts of the case warrant.

\section{THE BENEFITS AND COSTS OF THE PROPOSED APPROACH}

\section{A. Benefits of the Proposed Approach}

Applying tampering statutes to pretrial settlements in rape prosecutions will help remedy some of the harms of pretrial settlement by deterring defendants from offering pretrial settlements in order to influence complainants not to cooperate with the prosecution. This will reduce one pressure on the complainant not to testify. Further, more defendants will be likely to plea bargain, because they will be unable to sabotage the prosecution with a pretrial settlement. ${ }^{128}$ Plea bargaining also obviates the

${ }^{122}$ See Part I.B.

${ }^{12}$ See Part I.A.

${ }^{124}$ See note 15 and accompanying text.

${ }^{15}$ Compare Lichens, 5 Cal Rptr at 541 (described in text accompanying notes 72-76).

${ }^{135}$ See Ali, 1996 Tenn Crim App LEXIS 617 at *8 (recounting defendant's offer of cash so the money would not have to be reported to the IRS and how the defendant initially discouraged the victim's husband from involving an attorney).

${ }^{127}$ See State $v$ Sanders, 66 Wash App 878, 833 P2d 452, 459 (1992) (holding that evidence that the statutory rape defendant first encouraged his wife to make the complainant, her daughter, stop her accusations and then moved his wife and the complainant to a home in another state was sufficient to convict him of witness tampering).

${ }^{123}$ Note that most rape prosecutions are resolved by plea bargain. See Marsh, Geist and Caplan, Rape and the Limits of Law Reform at 34 (cited in note 3) (finding that in Michigan 66 percent of rape convictions were the result of a plea bargain). Although plea bargains and pretrial settlements both avoid trial, there are two crucial distinctions between them. First, the prosecutor negotiates the plea bargain without any fear of trial to 
need for the victim to testify, thereby protecting any interest she may have had in avoiding trial. ${ }^{129}$

Scrutinizing pretrial settlement will also discourage false accusations. An accuser who uses her participation in the criminal prosecution as a bargaining chip in settlement negotiations would be liable for accepting a bribe ${ }^{130}$ or compounding a crime ${ }^{131}$ for the same reasons a defendant trying to affect the complainant's cooperation with prosecutors would be guilty of tampering. The false accuser may thus not be able to settle until after the conclusion of the criminal trial, when there is no threat of tampering liability, and the complainant must expend her own resources to continue litigation. After the criminal trial, the false accuser's bargaining position is also weaker, as (presumably) the defendant will have been found not guilty. ${ }^{132}$

Scrutiny of pretrial settlements under tampering statutes deters false accusations without hurting the interests of bona fide complainants. In the past, courts have protected defendants against false accusations by raising the substantive requirements for a rape conviction. ${ }^{133}$ That approach protected rapists as well as

weaken her bargaining position. The prosecutor can thus reach a plea bargain that incorporates the full expected value of criminal sanctions. Second, a plea bargain employs uniquely criminal punishments. The defendant must plead guilty to a crime, thereby acknowledging guilt. As a convicted criminal, the defendant becomes an object of social stigma. If the plea bargain includes a prison sentence, the defendant will be incapacitated for some time.

${ }^{129}$ This will partly protect the interest of victims in not testifying. Some defendants, however, will not plea bargain, and in those cases some complainants will refuse to testify. In this situation, prosecutors should continue to exercise their discretion, usually to drop the charges. Deferring to the wishes of a witness that is adamant about not testifying allows some rapists to escape justice. However, the proposal crafted in this Comment merely addresses the harms of pretrial settlement. If, free of the influence of pretrial settlement, the complainant cannot bring herself to testify, the law should not compound the rape with further imposition.

130 See note 51.

${ }^{13}$ See note 53.

${ }^{132}$ There is, of course, the possibility that an innocent man would be convicted of rape. Given the exceedingly low conviction rate for rape, the likelihood that a wrongly accused defendant would be convicted is very small. See Marsh, Geist and Caplan, Rape and the Limits of Law Reform at 31 (cited in note 3) (citing studies that 4 or 5 percent of rape arrests end in convictions). Judges and juries have historically been very skeptical of rape accusations. Id at 91 (reporting a Michigan study finding that of prosecutors, police, defense attorneys, and judges, judges were most likely to believe that complaints for rape were fabricated more often than for other crimes). See also Battle $v$ United States, $630 \mathrm{~A} 2 \mathrm{~d}$ 211, 217 (DC App 1993) (noting that the prosecution must overcome "an implied charge of recent fabrication, which springs from some jurors' assumptions that sexual offense victims are generally lying"). A falsely accused defendant has an incentive to make a pretrial settlement, because even if acquitted, he will suffer the stigma of trial. Nonetheless, discouraging pretrial settlement, by reducing the number of false accusations, benefits potential victims of false accusations ex ante.

${ }^{133}$ See Schulhofer, Unwanted Sex at 26-27 (cited in note 18). New York courts in the 
falsely accused defendants. The alternative proposed by this Comment discourages accusations motivated by spite or greed without protecting guilty defendants at trial.

Applying tampering statutes to pretrial settlement will also benefit bona fide complainants by ensuring that more state resources are allocated to prosecuting rape charges. The proposed solution would reduce the number of complainants who decide not to cooperate with the prosecution as a result of pretrial settlement, leading prosecutors to have to drop fewer rape charges. Since there will be fewer false complaints and defendants will be unable to buy their way out of charges, police, prosecutors, and courts will take complaints more seriously and treat a complainant's accusation with less suspicion and more respect. ${ }^{134}$ Prosecutors will have more confidence that a complainant will see the case through to conviction, and they will have greater incentives to investigate rape allegations. ${ }^{135}$ Greater prosecutorial efforts to investigate rapes will increase convictions. ${ }^{136}$

Finally, society will be better educated about the scope of the rape problem. Since fewer nonindigent defendants will be able to buy their way out of a trial, the visibility of rape law enforcement will increase. Trial and conviction of more nonindigent defendants will also dispel the myth that the typical rapist is an indigent stranger. ${ }^{137}$

$1950 \mathrm{~s}, 1960 \mathrm{~s}$, and $1970 \mathrm{~s}$ strictly required that every material fact testified to by the complainant be corroborated by independent evidence. Id. In a typical year in the early 1970s, there were only eighteen rape convictions in New York. Id at 27.

${ }^{134}$ See Posner, Sex and Reason at 388 (cited in note 24) (arguing that suspicious judges and police reduce the deterrence of rapists).

${ }_{100}$ Prosecutors are concerned about devoting resources to cases that they cannot successfully complete. Consider Cheryl Hanna, No Right to Choose: Mandated Victim Participation in Domestic Violence Prosecutions, 109 Harv L Rev 1849, 1892 (1996) (arguing that prosecutors must be willing to mandate victim participation to prevent the waste of state investigatory resources that occurs when victims renege on testifying and to ensure that the state's response to domestic violence is not undermined). Some prosecutors subject complainants to detailed interrogations to test the complainant's ability to face crossexamination at trial. Marsh, Geist and Caplan, Rape and the Limits of Law Reform at 89 (cited in note 3).

${ }^{136}$ Concededly, the proposed approach would operate only on the margin. Evidence suggests that reform of substantive rape law has affected the arrest and conviction rates of rapists only a small amount. Robert Bachman and Raymond Paternoster, A Contemporary Look at the Effects of Rape Law Reform: How Far Have We Really Come?, $84 \mathrm{~J}$ Crim L \& Criminol 554, 556 (1993) (noting that many studies find "weak and inconsistent support for the assumption that rape law reform has had a substantial impact on the criminal justice system's processing of rape cases"). However, "rape shield laws and modifications in the consent standard have, in fact, increased the probability that victims of rape will report their victimization to the police." Id at 565.

${ }^{13}$ See note 31. 


\section{B. Costs of the Proposed Approach}

Admittedly, this proposal raises some concerns. Foremost is the fact that judicial scrutiny of (at least nominally) civil settlements interferes with the autonomy of the parties, preventing them from disposing of their claims as they see fit. Parties to civil litigation are generally free to settle any existing or potential claims between them. However, all bribery. laws interfere with private agreements. After all, a bribe is merely a contract for the exchange of money for services (favorable testimony). Bribes are illegal, however, because of their public consequences: obstruction and subversion of criminal and civil justice. ${ }^{138}$ Likewise, pretrial settlements, as private contracts, are presumptively legal. But when an offer of pretrial settlement is intended to obstruct the rape prosecution, the autonomy of the parties is superceded by the interest of society in protecting the administration of justice, as embodied in tampering statutes. ${ }^{139}$

Another consideration is the complainant's interest in receiving compensation from the defendant. A rape victim is likely to have medical bills and attorney's fees. She may also suffer lost wages from missed work. Although the proposed approach would deter some pretrial settlement, it would largely protect the victim's interest in compensation. First, the proposal would not affect settlement after the criminal trial. Rather than eliminating settlement, the proposal would tend to postpone it until after the criminal trial. Second, courts can award restitution to the complainant as a criminal sanction. ${ }^{140}$ Restitution is an alternative to civil settlement that can protect the interests of complainants, particularly those who cannot afford the cost of pursuing civil remedies on their own. ${ }^{141}$

\footnotetext{
${ }^{138}$ See text accompanying notes 61-63.

${ }^{139}$ Consider also the social benefits of applying tampering statutes to pretrial settlements discussed in Part IV.A. As this Comment acknowledges, some rape victims may be harmed by a disincentive for defendants to settle. However, if society is willing to make interpersonal trade-offs of costs and benefits, then applying tampering statutes to pretrial settlement should yield a social gain. Also, as noted above, although some rape victims may be hurt ex post, potential rape victims may prefer ex ante the approach this Comment advocates. See generally Lobsenz, 15 Crim L Bull at 313 (cited in note 16) ("To defer to courtroom phobia is to endanger future victims of crimes solely in order to ease the trauma of a present victim.").

${ }^{10}$ All fifty states have already enacted some statutory restitution law, and at least twenty-three states historically have mandated it by statute in criminal cases. Courts also have inherent common law power to order restitution in criminal cases. See Linda F. Frank, The Collection of Restitution: An Often Overlooked Service to Crime Victims, 8 St John's J Legal Comment 107, 111-12 (1992).

${ }^{13}$ See id at 112-13 (suggesting that criminal restitution remedies difficulties in obtaining civil recovery). If the court does not order restitution, however, postponing settle-
} 
Third, applying tampering statutes to pretrial settlement may raise the costs of reporting rape, by creating a disincentive to report for those victims who would prefer to make a pretrial settlement. However, evidence from the domestic violence context indicates that the chilling effect on reporting would be minimal. Some district attorneys have adopted a policy of prosecuting domestic violence cases regardless of the wishes of the complainant. ${ }^{142}$ In those jurisdictions there is no evidence of a chilling effect; in fact there is evidence that reporting of domestic violence has increased. ${ }^{143}$

Finally, the application of tampering statutes to pretrial settlements may incriminate not only corrupt defendants but unwitting complainants who accept settlement offers. However, tampering statutes, properly construed, apply to pretrial settlements without exposing bona fide victims to liability for accepting bribes. Initially, the language of those statutes prohibiting the solicitation or acceptance of payments not to prosecute almost always mirrors the language of statutes prohibiting the offering or conferring of a payment. In some states, the liability for compounding a crime is greater for one who receives the payment not to prosecute than for the defendant who offers the payment. However, specific intent-that is, intent to influence a witness or victim, or intent to be influenced in exchange for the payment-is required to establish a violation of tampering statutes in almost every state. ${ }^{144} \mathrm{~A}$ complainant may have compelling reasons unre-

ment until after the criminal trial may leave some complainants with little relief. A complainant lacking the resources to threaten a civil trial credibly will be unable to extract a settlement without the criminal prosecution as leverage. It is likely, however, that the willingness of the plaintiffs' bar to accept cases on a contingency basis would alleviate this problem.

${ }^{142}$ Hanna, 109 Harv L Rev at 1853, $1862-63$ (cited in note 135). It is worth noting that such a "no-drop" rule in rape prosecutions would be an undesirable alternative to the proposal set forth above. Such a rule would have the positive effect of reducing the incentive to attempt to bribe a complainant to request that charges be dropped, but the possibility of compelled participation in a traumatic trial might have the negative effect of harming victims and could antagonize the complainant-prosecutor relationship. For discussion of the dilemmas posed by no-drop policies, see id at 1865-66.

${ }^{143}$ Id at 1865 n 72, 1896-97.

${ }^{14}$ See, for example, Gill v State, 622 S2d 92, 93 (Fla App 1993) (construing Fla Stat Ann $\$$ 914.22(1)(e) (witness tampering)). Some courts have held there is no requirement of specific intent in cases involving threats and force. See, for example, State $v$ Gray, $435 \mathrm{~S} 2 \mathrm{~d}$ 816, 820 (Fla 1983) (holding that Fla Stat Ann $\S 918.14(3)(a)$ (1979) does not require a showing of scienter or specific intent because the legislature did not specifically include those elements in the statute); Smith $v$ State, 902 P2d 1271, 1281 (Wyo 1995) (finding Wyo Stat Ann $\S 6-5-305(a)$ (1988), which proscribes "attempts to influence, intimidate or impede" witnesses, does not require specific intent). However, most courts require specific intent, even for tampering involving threats or force. See, for example, People $v$ Lyons, 235 Cal App 3d 1456, 1 Cal Rptr 2d 763, 765 (1991) (construing Cal Penal Code $§ 136.1$ (dis- 
lated to the offer of money not to seek prosecution; to the complainant the settlement may be independent from the prosecution. Thus, it is perfectly consistent to find that the defendant intended to influence the complainant and that the complainant did not intend to be influenced, but rather was motivated by her own desire to avoid trial. ${ }^{145}$

\section{CONCLUSION}

Pretrial settlements in rape prosecutions undermine the effective enforcement of rape law. Since the complainant is also almost always the primary witness in a rape trial, pretrial settlement in rape cases is more likely to be used to influence the complainant's cooperation in the prosecution than in other crimes. Consequently, an interpretation of a bribery statute that fails to reach pretrial settlements that (explicitly or implicitly) influence the complainant not to cooperate with the rape prosecution will fail to deter bribery.

Pretrial settlements, by their nature, are rarely subject to judicial review; consequently, few courts have examined them for violation of tampering statutes. When faced with such a case, a court should closely scrutinize the pretrial settlement and allow the finder of fact to infer intent to prevent a rape prosecution from the circumstances of the case.

Interpreting tampering statutes to apply to pretrial settlements, at least in the context of rape prosecutions, is consistent with the text and purpose of tampering statutes and will alleviate some of the harms of pretrial settlement. Such an interpretation recognizes the potential use of pretrial settlement to influence complainants to seek an end to prosecutions; it deters such forms of corruption and thereby protects enforcement of rape law.

suading witness from testifying) to require a showing of specific intent); State $v$ Hall, 441 S2d 429, 431 (La App 1983) (construing La Rev Stat Ann § 14:122 (public intimidation) to require a showing of specific intent).

${ }^{15}$ Recall that a bilateral agreement is generally not required to find violation of a tampering statute. See notes 68-69 and accompanying text. 